\title{
Models of regional competitiveness: priority influencing factors
}

\author{
Andrea Čajková1 ${ }^{*}$, Evgenya Romanova ${ }^{2}$, Svetlana Tolstikova ${ }^{2}$, and Boris Abushkin ${ }^{2}$ \\ ${ }^{1}$ University of Ss. Cyril and Methodius, Department of Public Administration, Faculty of Social \\ Sciences, Bučianska 4/A, 91701 Trnava, Slovakia \\ ${ }^{2}$ Moscow City University, 4 Vtoroy Selskohoziajstvenny proezd, Moscow, 129226, Russian Federation
}

\begin{abstract}
This study examines the conceptual background to specific aspects of competitiveness and examines one of the fundamental models for improving regional competitiveness. Regional competitiveness is an important factor of achieving economic growth and increasing the wellbeing. It plays a decisive role in enhancing the productivity and the economic performance of state and business enterprises and can also be used as a measure for the success of these enterprises as well as the proxy for their degree of openness to national and international competition and foreign trade. Furthermore, we present a theory of the movement of labour capital between regions and countries. Moreover, we show that factor allocation deviates from the most efficient outcome when the market is not working.
\end{abstract}

Keywords: regional competition, labor capital, barriers to capital movement, distribution of factors.

\section{Introduction}

In order to investigate the impact of opening up to foreign trade (FDI) on industrial agglomeration, one can look at the interaction between regional access to FDI and industry dependence on FDI. There are two broad theories to explain the effects of foreign trade openness on the distribution of output in a country, both of which concern a comparative advantage in terms of economies of scale $[1,2]$. New trading models are based on the assumption of increased returns on scale, product differentiation, market structure and monopolistic competition. In order to identify the various causes of this increase, one can distinguish between two main types of increase in returns on scale [3].

In general terms, it is stemming from the regional economics literature that all factors influencing regional competitiveness are divided into two groups: direct and indirect. The most important are the fundamental factors that have an immediate short-term impact on economic performance (e.g. profitability and labour productivity) $[4,5]$. The presentation of the characteristic factors contributing to the objective of determining competitiveness is structured in the pyramid model of regional competitiveness. Here, cluster represents an integrated system of large groups and service companies with complex strategies and regional business structures that ensure competitiveness by taking into account interconnected sectors

\footnotetext{
*Corresponding author: andrea.cajkova@ucm.sk
} 
and interests. The cluster approach, which provides a region with stable development and competitiveness, contributes to different sectors, companies or a combination of the two [6, 7]. This approach will be implemented taking into account the efficient use of internal resources aimed at the economy and modernisation of the regions, so as to increase the competitive advantage of the regions through stable development, competitiveness and territorial research.

There are also indicators of innovation and level of development of countries proposed in the World Economic Forum's Global Competitiveness Report using the technique of multivariate data analysis [8]. The aim is to identify the factors of innovation responsible for achieving the highest level of development. In addition, it is important to understand which of these factors should be prioritised when countries are among the most competitive [9]. The results indicate that the factors tested are the determinants that lead to countries in their development phase. This can be confirmed, for example, by the results of some recent studies. For each regional panel in the database, a set of indicators and their impact on GDP per capita were tested using a fixed-time cross-section, a fixed-time random effect model and a dynamic Arellano-Bond panel for data estimation [10]. The results indicate that some regions in the European Union where entrepreneurial sophistication and labour market areas are considered as priority areas for regional economic development planning. Of particular interest is the link between competitive industries and the economy. Although the results of these case histories lag behind the work of the best historians in terms of detail, they offer insights into the development of industries in an economy [11]. The famous book by Michael Porter entitled "Competitive Advantage in Nations" contains a detailed description of the nation and helps to study the future prospects of the world's economies [12]. The accompanying article focuses on the determinants of competitive advantage in individual industries and outlines the general impact of the studies on government policy and corporate strategy. For a more comprehensive treatment, a new theory of how countries gain competitive advantages and deepen their impact should be developed offering additional examples from all around the world.

In short, modern conditions and the state of the world's economic, social and technological development ensure stable development and competitiveness of regional economies and contribute to faster modernisation. Complex analysis and organization of economic development paths ensures stability and competitiveness of regional economies as the basis of activities aimed at optimizing the regional production structures.

\section{Relative weights and competitiveness in the regional development}

From the theoretical point of view, regional competitiveness index can be formed from relative weights and linear combinations. The influence of weighting on a single score depends on the scaling, normalization and step values of the weight itself [13]. The improper allocation of relative weights is particularly noticeable in cases where there is multilinearity or co-linearity between independent variables. Relative weights are a crucial component of economic infrastructure that can be evaluated by zero-order correlation structures (coefficient analysis, beta-coefficient analysis, product measurement analysis, relative weight analysis and commonality analysis). Appropriate techniques for index formation can be identified as Pearson correlation and Spearman rank correlation analysis. Despite the lack of thorough social research, these indicators offer a convergence in employment in the regions [14]. The level of employment reflects the sensitivity.

Thence, the analysis of regional competitiveness can be carried out as a competitive jurisdiction by reconciling international business and public policy with clear and shared international ambitions [15]. Economic competitiveness is the result of productive 
partnerships between government and businesses and main competitors understand how important this type of relationship is [16]. The primary benefits lie in natural resources, diverse economies, high-quality public education, and institutional and political stability [17]. Even though some regions and countries receive mixed reviews compared to other countries in various competitiveness rankings studies, a simple and feasible conclusion can be drawn from these results [18]. In order to assess regional development prospects, one should look at the strengths and weaknesses of the factors influencing the ability of a given region or a country to attract investment, build competitive businesses, and create quality employment opportunities for its citizens. Such instruments as Weighted Life Cycle Assessment (LCA) that takes into account the preferences of stakeholders in the decisionmaking process of comparative LCAs can be used. Life Cycle Assessment research has focused on the derivation of weights according to different principles, and few studies have investigated the relationship between the normalization of weights and their impact on a single score [19].

\section{Regional economy and the assessment and enhancement of regional development}

Ensuring that there are vibrant and thriving communities that can compete globally requires a comprehensive and actionable approach to economic development, education, economic mobility and other critical factors [20]. One of the aims of this research is to examine connectivity, competitiveness and resilience and propose a financial framework for a concerted strategy for competitive and resilient regions. Our research strategy deals with the development of regions in the European Union.

In 2010, the European Commission called national and regional governments to develop a smart specialisation strategy for research and innovation (R\&I) in order to encourage European regions to discover their competitive advantages. The new smart specialisation approach has become the basis for investment in research and innovation at the European Regional Development Fund (ERDF) under the 2014-2020 program period for research and innovation [21]. In a few years, some $\$ 48$ million had been mobilised to support 18 new research projects.

The scope of the EU Solidarity Fund has been extended to cover major emergency situations in the field of public health, so that Member States can receive help from the Fund to help them with the COVID-19 crisis [22]. In this context, the European Commission has agreed aid measures notifying Member States and the United Kingdom by the World Health Organisation. By mobilising non-relative funds allocated to EU Member States, this initiative provides an immediate cash boost for Member States' and Regions' budgets and helps them to use Cohesion Policy funds to finance health expenditures, short-term work programs and to support small and medium-sized enterprises with working capital [23]. It called for continued efforts to promote interregional cooperation and recalled the importance of innovation systems, institutions and links between local and regional clusters as it noted in 2016 as well as cohesion policy and smart specialisation strategies. In its resolution from 2016, it stated that the Structural Synergy Innovation Fund (called "Horizon 2020") and other policy instruments should be improved to maximise the impact of investments [24].

Here, we also briefly discuss the ways in which researchers can implement empirical strategies to achieve credible treatment effects estimated from datasets describing urban and regional phenomena. Our treatment emphasizes the importance of randomization, which has also been recognized in other areas of development economics (randomized studies are an important tool for restoring treatment effects of interest for political evaluation). However, evaluations are often carried out on specific programmes, in contrast to the general regional development efforts in view of the challenges of allocation. An attempt to look at the policy 
assessments carried out by the institution such as, for example, English Regional Development Agency found that more than half of the benefits came from less than $20 \%$ of expenditure [25]. Inadequate sub-national governance capacities and other governance challenges are one of the most neglected areas of regional development policy. One reason why these issues are not a high priority in some countries is that they are not part of the mandate of regional development ministries, and therefore do not include regional development policies around these issues [26]. Sub-national governance capacity is an obstacle to growth in many backward regions, and only half of OECD countries classify it as a priority for regional development. The concept of competitiveness plays an important role in economic policy for regional development [27].

In short, the current economic development programmes are responsible for the increased attention devoted to the analysis of regional competitiveness. With regard to the above, some studies examine the conceptual background and the specific aspects of competitiveness and draw fundamental models for improving regional competitiveness by developing the tailormade economic data and training to meet the needs of states. Capital regions that refer to regions that include the capital of the country, to which the rest of the region belongs, which can, of course, be combined with others. All of the 28 EU Member States have at least one region at NUTS2 level and the results show a polycentric pattern, with capital regions performing well in many parts of the EU. In addition, it appears that the capital regions in the European Union tend to be more competitive than their countries, with the usual exceptions of Germany, Italy and Netherlands [28]. Structural models are inherently full of assumptions, and strong assumptions must be made about the use of randomization to restore treatment effects. Some models fail to clearly specify such theories by deriving treatment effects from credible data-based identifications, as we discuss below.

\section{Geographical competitiveness and its role in attracting labour and capital}

From the point of view of the economic theory, restrictions that move workers slow down the economic growth and make it harder for companies to hire productive workers. At the same time, unlimited work depresses wages in certain sectors and creates unemployment [29]. The degree to which the workforce is mobile influences how quickly the economy adapts to technological change and how quickly competitive advantages can be exploited in the development of innovative industries. When unproductive firms are replaced by innovative ones, the economy becomes more efficient. Companies are hiring more efficiently than others, wages are rising, and workers' living standards are improving. The decline in start-ups since 2000 has been most pronounced in high-tech companies and industries [30].

Thence, for understanding the regional competitiveness is now becoming better, it is important to investigate how increasing market concentration reduces the market entry of companies. Fewer small start-ups mean less competition for established companies. Dominant companies crowd out new entrants and reduce entrepreneurship, but at the same time the lack of start-ups reduces the market players needed to create competition. When a national environment allows and supports the rapid accumulation of specialized assets and skills, as well as great effort and commitment, companies gain a competitive advantage [31]. Under pressure and challenge, they gain an advantage over the world's best competitors. A national environment forces companies to innovate and invest in order to gain a competitive advantage and to develop that advantage over time. A national environment provides ongoing information and insight into the products and processes that companies need to gain a competitive advantage. The sample of nations and industries provides a rich empirical basis for developing and testing new theories about how countries gain competitive advantages [32]. Thence, one should focus on the determinants of competitive advantage in individual 
industries and outlines the general impact of the studies on government policy and corporate strategy. Only if one is capable of understanding her or his competition can they assess their own market position. From there, one can exploit its weaknesses and competitive advantages and try to improve their own marketing efforts. Then, it helps to integrate the competitive analysis with the demographic analysis of the market to develop and implement marketing strategies that strengthen the market positions. An in-depth analysis of the competition is one of the most important elements of a comprehensive market analysis.

Competitive analysis enables business companies to assess the strengths and weaknesses of their competitors in their specific national and international market and implement effective strategies to enhance their competitive advantage. Various methodological guides provide a through a step-by-step process of competitive analysis to help the companies to identify their competitors, identify and weigh their attributes, assess their strengths and weaknesses, and uncover their objective strategies for their market segment [33]. To gain a strong competitive advantage, one needs to create and support an ecosystem of complementary products and services derived from third-party relationships. These relationships can then support the scaling of an organization and minimize financial risk.

\section{Conclusions}

According to popular economic theory, the factors of production determine the flow of trade - labour, land, natural resources - capital and infrastructure. Nations export the goods that make the most use of the factors for which they are well equipped. A country has an advantage when it has a certain natural resource. For example, in a country where capital and land abound and labour is scarce, there is a comparative advantage to goods that require a lot of capital, land, and little or no labour, such as grain. For example, a country with rich oil resources can extract oil. When Saudi Arabia produces oil, it has a comparative advantage in oil, because it can export it to finance its purchases and imports.

Classical theory explains a nation's success in a particular industry based on so-called factors of production, such as land, labour and natural resources. Skilled workers are cheaper and more productive than unskilled workers. Many products have the advantage of being produced on a large scale and production costs are reduced. The Ricardian model of comparative advantage considers a single factor of production, labour, which, due to technological differences between countries, is unable to generate a comparative advantage because nations in different stages of growth become self-sufficient for reasons of trade among themselves. The Ricardian model eliminates technological variations and introduces the capital variable to restore the transnational variation in labour productivity that the model imposes. The international variation in capital, infrastructure, and goods requires different proportional factors, and Ricardo's comparative advantage proves to be the profitmaximizing solution to the capitalist electoral equation. The model represents a stylized case in which developing country 1 has a large population with low wages and developing country 2 a small population with high wages. Based on free labour mobility and migration costs, workers in country 1 have an incentive to move to country 2 where wages are higher. As a result, trade theory suggests that different countries specialize in different goods and services over which they have a comparative advantage. Different production technologies and differences in the availability of natural resources (factor prices vary from country to country, and labour and capital flows are expected where permissible). The pace of technological progress is also unevenly distributed, providing incentives for migration factors. This article seeks to contribute to previous scientific work by operationalizing the concept of attractiveness of a country that has been discussed and popularized in the fields of international economy, tourism and migration from a sustainable development perspective in many dimensions and providing theoretical building blocks to explain the effects of this 
concept. In the twentieth century, international economists offered a number of theories to explain why differences in countries' productivity factors determine a comparative advantage in patterns of international trade. As mentioned above, classical British economists accepted the fact that there exist productivity differences between countries, but made no concerted effort to explain how their commodities are exported and imported (these include factors such as interest in quality of life and concern about climate change). For example, countries in several competitive areas, such as international tourism and migration, must be attractive to future tourists and highly skilled immigrants to succeed in these sectors. In the sector of export sales and foreign direct investment markets, the high attractiveness of a country has a positive impact on the sale of goods and services manufactured in the country of origin to host industries, companies and factories to attract international consumers and investors. However, this approach, which favours companies over governments, is flawed. Innovation can create competitive advantages by seizing new market opportunities and serving market segments that others have ignored. For example, in industries such as automotive and home electronics, Japanese companies gained their first advantage by highlighting small, compact, and low-capacity models foreign competitors despised as less profitable, less important, or less attractive. Competitors reacted slowly, and such innovations brought competitive advantages.

Overall, we can conclude by saying that regional competitiveness is becoming an important and complex tool for the economic development. Factors that influence its priorities and functioning should be better studied and implemented using the support of the governments as well as the private sector for both of them have an interest in promoting its growth and success.

Acknowledgements: Creative project practice of self-presentation of a young specialist in a professional environment, Contract No. GSGK-89/20 of 12.08.2020

\section{References}

1. T. Palley, European Journal of Economics and Economic Policies: Intervention, 15(2), 174-192 (2018)

2. K. Siddiqui, International Critical Thought, 8(3), 426-452 (2018)

3. R. Feenstra, Journal of Economic Perspectives, 32(2), 25-46 (2018)

4. J. Short, D. Ketchen T. Palmer, G. Hult, Strategic Management Journal, 28(2), 147-167 (2007)

5. M. Kabir, R. Salim, N. Al-Mawali, Economic analysis and policy, 56, 60-71 (2017)

6. V. Prokhorova, V. Chernikova, T. Anopchenko, L. Goloshchapova, N. Kulikova, Espacios, 39(31), 25 (2018)

7. G. Khmeleva, N. Tyukavkin, S. Sviridova, D. Chertopyatov, Economic and Social Changes: Facts, Trends, Forecast, 5, 83-98 (2017)

8. A. Dima, L. Begu, M. Vasilescu, M. Maassen, Sustainability, 10(6), 1706 (2018)

9. I. Cabelkova, W. Strielkowski, Society and Economy, 35(4), 513-529 (2013)

10. A. Selase, American International Journal of Humanities, Arts and Social Sciences, 1(2), 47-57 (2019)

11. M. Stanickova, L. Melecký, Regional Studies, Regional Science, 5(1), 231-254 (2018)

12. M. Porter, Competitive advantage of nations: creating and sustaining superior performance (2011) 
13. S. Radosevic, E. Yoruk, Technological Forecasting and Social Change, 129, 56-75 (2018)

14. S. Rahmat, J. Sen, Journal of Urban \& Regional Analysis, 13(1), 35-57 (2021)

15. J. Niño-Amézquita, V. Dubrovsky A. Jankurová Czech Journal of Social Sciences, Business and Economics, 6(1), 28-36 (2017)

16. A. Vogt-Schilb, S. Hallegatte, Wiley Interdisciplinary Reviews: Energy and Environment, 6(6), e256 (2017)

17. P. Koudelková, W. Strielkowski, D. Hejlová, Danube: Law, Economics and Social Issues Review, 6(1), 25 (2015)

18. B. Rodríguez-Díaz, J. Pulido-Fernández, Journal of Travel Research, 60(2), 267-280 (2021)

19. J. Sohn, P. Bisquert, P. Buche, A. Hecham, P. Kalbar, B. Goldstein, S. Olsen, Sustainability, 12(6), 2170 (2020)

20. P. Čajka, Central European Political Studies, 4, 131-148 (2019)

21. M. Landabaso, European Journal of Innovation Management, 17(4), 378-389 (2014)

22. A. Jones, K. Sergejeff, A. Sherriff, C. Teevan, P. Veron, https://euagenda.eu/upload/publications/the-challenge-of-scaling-up-the-europeanunion-s-global-response-to-covid-19.pdf(2021)

23. R. Leonardi, Cohesion policy in the European Union. The Building of Europe (2005)

24. M. Ferry, S. Kah, European Structural and Investment Funds Journal, 4(3), 161-175 (2016)

25. A. Pike, M. Coombes, P. O’Brien, J. Tomaney, Territory, Politics, Governance, 6(1), 118-144 (2018)

26. W. Strielkowski, E. Volkova, I. Pushkareva, D. Streimikiene, Energies, 12(7), 1392 (2019)

27. M. Uhoda, Journal of Social and Economic Development, 22, 91-112 (2020)

28. P. Annoni, L. Dijkstra, Measuring and monitoring regional competitiveness in the European Union (2017)

29. D. Acemoglu, P. Aghion, F. Zilibotti, Journal of the European Economic association, 4(1), 37-74 (2006)

30. M. Porter, Attitudes, values, beliefs, and the microeconomics of prosperity. Culture Matters (2000)

31. S. Nambisan, D. Siegel, M. Kenney, Strategic Entrepreneurship Journal, 12(3), 354-368 (2018)

32. H. Saranga, R. George, J. Beine, U. Arnold, Journal of Business Research, 85, 32-50 (2018)

33. W. Liu, K. Atuahene-Gima, Industrial Marketing Management, 73, 7-20 (2018) 